\title{
PELAYANAN PENDIDIKAN KEAGAMAAN PADA KOMUNITAS ANAK JALANAN KOTA MEDAN
}

\author{
Oleh : Faiqoh \\ Peneliti Puslitbang Pendidikan Agama dan Keagamaan \\ Jl. Thamrin No. 06 Jakarta Tlp/Fax. 021-3920379
}

\begin{abstract}
Every citizen has the right to education. There is no difference between one citizen and another. Citizens with physical, emotional, mental, intellectual and / or social disorders shall be entitled to special services. Ideally, street children get education access both general education and religious education. However, it is still unknown how street children acquire adequate education, especially religious education. Using a case study, this paper is intended to explore how religious education services are provided to street children in Medan.
\end{abstract}

Keywords: Religious Education Services, Street Children Community

Abstrak

SetiapwargaberhakmendapatPendidikan.Tidakadaperbedaanantarasatuwarganegaradengan warga negara lainnya. Warga negara yang mempunyai kelainan fisik, emosional, mental,intelektual dan/atau sosial berhak memperoleh layanan khusus. Idealnya anak jalanan mendapat pemenuhan Pendidikan baik Pendidikan umum maupun Pendidikan keagamaan. Namun, masih belum diketahui bagaimana anakjalanan memperoleh Pendidikan secara memadai, terlebih lagi Pendidikan keagamaan. Dengan menggunakan studi kasus, tulisan ini ingin menggali bagaimana pelayanan Pendidikan keagamaan diberikan kepada anak jalanan kota Medan.

Kata kunci: Pelayanan Pendidikan Keagamaan, komunitas anak jalanan

\section{PENDAHULUAN}

Fenomena anak jalanan muncul setelah Indonesia dilanda krisis dimulai pertengahan Juni 1997. Sebenarnya sebelumnya sudah ada, hanya kondisinya tidak separah seperti sekarang ini. Kita dapat menjumpai anak-anak jalanan ini hampir di setiap perempatan kota-kota besar di Indonesia. Bahkan di kota-kota kecil seperti Solo, Karanganyar, Boyolali pun kita dapat menemui anak-anak ini. Ada yang berprofesi sebagai pengamen, pengemis, tukang lap kaca mobil, tukang semir sepatu dan tak sedikit pula yang menjajakan barang dagangan seperti rokok, lap keringat atau sapu tangan, permen, dan lain-lain.

Tidak sedikit dari anak-anak jalanan ini yang belum menyadari bahaya yang dapat mengancam rnereka. Mereka berada diperempatan lampu merah dimana mobil-mobil yang berseliweran yang melaju dengan kecepatan tinggi yang dapat rnembahayakan jiwa mereka. Namun sepertinya hal ini tidak membuat mereka mundur dari profesi yang dijalaninya.

Naskah diterima, 20 Januari 2012. Revisi pertama, 1 Februari 2012, revisi kedua 15 Februari 2012, revisi ketiga 20 Maret 2012 
Mungkin karena faktor desakan ekonomi yang membuat mereka tetap bertahan pada dunianya. Karena, krisis ekonomi yang melanda tanah air kita ini telah menambah panjang deretan orang-orang miskin. Efeknya terasa terhadap anak-anak yang kurang mampu ini.

Bahaya lain yang cukup serius adalah kemungkinan kita akan kehilangan generasi berikutnya. Kenapa? Anak-anak ini adalah calon-calon penerus bangsa dan pembangunan di masa depan. Mereka hidup di jalanan, sama halnya kita "membunuh" generasi di masa datang. Akankah kita menyerahkan tongkat kepemimpinan ini kepada generasi yang tumbuh di jalanan. Tentu tak seorangpun yang menginginkan hal ini. Anak-anak di masa pertumbuhan dan perkembangan cenderung mengikuti lingkungan. Secara bertahap anak-anak yang memilih ke jalanan akan mengalami perubahan perilaku yang cenderung melecehkan dan melanggar norma. Mereka mulai liar, cuek dan akhirnya membangun norma ala mereka. Hal ini terjadi pada ucapan, perilaku sampai seks bebas. Terbentuknya komunitas-komunitas anak jalanan yang merupakan peer group dimana ini berfungsi sebagai 'keluarga kedua' yang justru dimanfaatkan oleh anak-anak itu sendiri atau orang lain untuk tujuan kriminalitas dan asusila. Munculnya konflik, dimana keberadaan anak-anak di jalanan atau tempat-tempat ramai dan menjadi sektor informal bukan saja belum dilindungi hukum, namun pada akhirnya menimbulkan konflik dengan berbagai pihak baik pihak resmi seperti.kepolisian, Kamtib maupun masyarakat.

Munculnya anak yang bekerja di jalanan merupakan suatu dorongan (keterpaksaan) untuk memasuki usia produktif secara prematur. Sebagai anak yang seharusnya berhak memperoleh perlindungan, terpaksa mengalami situasisituasi sosial-ekonomi yang terlalu dini untuk diterimanya. Keadaan-keadaan itulah yang mengikatnya untuk turun ke jalanan, sehingga tidak ada lagi masa kanak-kanak yang indah bagi mereka. Yang ada hanyalah pikiran bagaimana untuk mempertahankan hidup hari ini. Namun tak jarang pula ini adalah wujud keinginan yang datang dari mereka sendiri, karena kenakalan dan sikap malas yang memang bawaan di jiwanya.

Selama ini anak jalanan terkesan negatip dimata masyarakat. Orang hanya tahu bahwa mereka adalah anak jalanan dan tidak mengenalnya lebih jauh. Masalah sosial ini sudah menjadi problematik bangsa, yang kemungkinan berawal dari konflik keluarga. Adanya eksploitasi terhadap anak-anak yang menjadikan mereka sebagai sapi perahan oleh orang-orang yang tidak bertanggungjawab.

Salah satu hak azasi yang harus diberikan negara terhadap warganya adalah hak mendapatkan pendidikan tanpa kecuali. Idealnya, anak jalanan, yang juga terlahir sebagai anak bangsa tersebut, mendapat pemenuhan pendidikan baik pendidikan umum maupun pendidikan keagamaan. Kiranya, hanya dengan pendidikan bisa membekali mereka keterampilan, pengetahuan dan agama untuk menjalani kehidupan dalam masyarakat, menentukan pilihan hidup, serta bekal berkompetisi dengan kelompok masyarakat lainnya. Namun, masih belum diketahui dengan pasti bagaimana anak jalanan memperoleh pendidikan secara memadai, terlebih lagi pendidikan keagaman. Maka, penelitian ini dengan menggunakan studi kasus ingin menggali sejauh mana praktek pendidikan agama dan keagamaan tersebut pada anak jalanan perkotaan. Secara khusus studi ini bertujuan untuk mengetahui dan mendeskripsikan tentang Profil anak jalanan, Bentuk-bentuk pendidikan keagamaan yang diperoleh anak jalanan; Lembaga apa saja dan siapa saja yang telah memberikan pendidikan keagamaan pada anak jalanan; Pengalaman pendidikan keagamaan pada anak jalanan. 
Penelitian ini dilakukan di kota medan Sumatera Utara, Pengumpulan data dilakukan dengan menggunakan beberapa teknik yaitu Studi Kepustakaan; Studi kepustakaan digunakan untuk menggali konsep, teori pendukung dan referensi yang ada kaitannya dengan masalah pokok penelitian. Wawancara; untuk memperoleh data dari informan secara langsung. Wawancara dilakukan dengan dua cara; formal dan informal. Wawancara formal adalah peneliti melakukan wawancara dengan terlebih dahulu memberitahukan kepada informan bahwa akan dilakukan wawancara. Sedangkan wawancara informal akan dilakukan kapan saja ketika peneliti menemukan informan dan bisa tidak memberitahukan terlebih dahulu kepada informan. Pengamatan; pengamatan diarahkan untuk menggali data yang tidak ditemukan dalam wawancara yang berupa tindakan, kebiasaan dan perilaku lainnya dari informan.

\section{KAJIAN PUSTAKA}

\section{Anak Jalanan}

Penggunan istilah anak jalanan mulai digunakan pada awal 1990-an ketika Childhope dan Yayasan Kesejahteraan Anak Indonesia (YKAI) melakukan penelitian tentang kelompok gelandangan anak. Dan kelompok inilah yang disebut anak jalanan. Penggunaan istilah anak jalanan diperkuat dengan keberadaan Lembaga Swadaya Masyarakat (LSM) yang tergabung dalam Konsorsium Anak Jalanan Indonesia. Pemilihan nama Konsorsium ini sekaligus "meligitimasi" penggunaan istilah anak jalanan di Indonesia secara luas.

Akan tetapi, studi tentang anak jalanan di Indonesia sudah dirintis sejak tahun 1980-an di kota besar, seperti Jakarta (Aan T Subhansyah, dkk). Studi selanjutnya, yaitu tahun 1993, Laboratorium Antropologi Universitas Indonesia bekerja sama dengan bagian Penelitian dan Pengembangan
Sosial Departemen Sosial melakukan studi di empat kota: Jakarta, Cirebon, Bandung dan Semarang. Studi tersebut lebih difokuskan pada pencarian sebab kenapa anak jalanan hadir. Disamping itu, studi ini juga dimaksudkan untuk mencari landasan bagaimana mengatasi anak jalanan. Kecenderungan lain adalah, mengkaji program penanganan yang telah dilakukan oleh lembaga-lembaga non pemerintah (NGO). Jadi, studi-studi yang belakangan lebih difaokuskan pada bagaimana intervensi yang telah dilakukan untuk menyikapi persoalan anak jalanan.

Studi yang agak makro dilakukan oleh Irwanto (1998) yang meneliti situasi anak jalanan di 12 kota besar di Indosesia. Studi ini dilakukan untuk merespon situasi kritis perekonomian saat itu, sehingga menjadi anak jalanan dapat dilihat sebagai pilihan terhadap kehidupan ekonomi. Studi lain dilakukan oleh Wahyu Nograha yang mengkaji Seksualitas Anak Jalanan. Studi ini mengambil fokus pada perilaku seksualitas anak jalanan yang ia katakana sebagai perilaku khas. Yang mengejutkan dari temuan studi ini bahwa hubungan seksualitas anak jalanan, yang mereka sebut esek-esek, itu rata-rata dimulai pada usia di bawah 12 tahun. Kategori hubungan sek tidak tunggal di sini. Setidaknya ada dua kategori hubungan sek disamping esekesek, seperti onani, dan homoseksual (sek oral dan sek anal). Berbeda dengan Wahyu Nugraha, Y. Argo Twikromo, mengkaji anak jalanan yang bekerja sebagai pemulung jalanan. Dalam studi ini Y. Argo T, mengkaji bagaimana peraturan pemerintah di suatu lingkungan kota telah mempengaruhi pandangan pemulung jalanan tentang realitas sosial budaya mereka (pemulung jalanan). Maka, temuan studi ini mengarah pada hubungan antara pemerintah dan pemulung jalanan yang dianggap sebagai hubungan yang mengucilkan dan memarginalkan keberadaan pemulung jalanan. 
Anak jalanan pada hakekatnya sebuah kategori sosial yang bisa dibedakan ke dalam dua kelompok yaitu anak yang bekerja di jalan dan anak yang hidup di jalan. Anak yang bekerja di jalan dicirikan masih memiliki kontak dengan orang tua, mengakui keberadaan kedua orang tuanya dan tinggal dengan orang tuanya. Anak yang hidup di jalan, adalah anak yang sudah putus hubungan dengan orang tua mereka maupun keluarga. Kategori kedua ini, merupakan perwujudan dari anak-anak yang bekerja dan tinggal di sembarang tempat di jalanan seperti emper toko, taman kota, terminal, stasiun dan seterusnya.

Ada perbedaan definisi dan batasan umur yang diberikan terhadap anak jalanan. Pengertian umum yang sering digunakan bahwa anak jalanan adalah (1) anak-anak yang benar-benar hidup dan bekerja di jalanan dan ditelantarkan dan telah lari dari keluarga mereka (2) anak-anak yang menjaga hubungan dengan keluarga mereka, tetapi menghabiskan waktunya di jalanan (3) anak-anak dari keluarga yang hidup di jalanan. Sedangkan dari sisi umur, menurut UU No. 4 tahun 1979, anak adalah mereka yang berusia di bawah 21 tahun. Departemen Sosial membatasi anak pada usia 7 - 15 tahun. Sementara Yayasan Kesejahteraan Anak Indonesia membatasi usia anak 6 - 15 tahun. Dan dalam The Minimum Age Convention on The Rights of The Chilld (1989), anak adalah mereka yang berumur 18 tahun ke bawah. Karena belum ada kesepakatan mengenahi umur anak, maka dalam penelitian ini mengambil batasan umur anak adalah 18 tahun ke bawah dengan alasan bahwa umur 18 tahun merupakan umur dari sekolah lanjutan atas. Dengan demikian, anak jalanan yang dimaksud dalam penelitian ini adalah anakanak yang berusia 18 tahun ke bawah terdiri dari laki-laki dan perempuan dan hidup di jalanan. Batasan usia ini juga sesuai dengan batasan usia yang dikemukakan dalam Undang Undang Perlindungan Anak yang menyebutkan bahwa anak adalah individu yang berusia di bawah 18 tahun.

Untuk menjadi anak jalanan, biasanya melewati proses. Anak yang baru terjun ke jalanan, belum mengenal dan dikenal siapapun di dunia barunya itu. Selain itu, mereka juga diliputi rasa kekhawatiran bila identitas dirinya diketahui orang lain. Untuk menjaga dan menghindari kekhawatirannya tersebut, mereka biasanya merubah identitas lamanya mulai dari mengganti nama, cara berpakaian maupun bahasa pergaulannya. Pergantian tersebut dilakukan dengan maksud untuk memutus rantai dengan masa lalunya sekaligus masuk dunia barunya. Ketika ia sudah berada di jalanan, ia menjelma dengan nama baru dan sebutan barunya. Anak-anak yang berasal dari pedesaan mengganti dengan nama-nama yang dianggap lebih modern, yang diambil misalnya dari bintang sinetron atau nama-nama yang sudah familier di telinga mereka seperti Alex, Roy, Iwan dan seterusnya. Proses penggantian ini sebenarnya bukan sekedar penggantian panggilan semata melainkan juga sebagai wahana menanggalkan masa lalunya, dan yang terpenting merupakan pernyataan untuk memasuki suatu dunia baru yaitu sebuah kehidupan jalanan. Dalam dunia pendidikan, anak jalanan termasuk dalam kelompok anak usia sekolah yang tereksklusi dan jarang mendapat perhatian serius dari pemerintah. Dalam konteks perundangan, mereka memiliki hak yang sama untuk memperoleh pendidikan, baik pendidikan umum maupun keagamaan. Di sinilah sebenarnya peran negara dituntut untuk menanganinya karena mereka pada hakekatnya juga anak bangsa.

\section{Pendidikan Keagamaan}

Dalam UU Sisdiknas Tahun 2003 disebutkan bahwa Pendidikan agama adalah pendidikan yang memberikan pengetahuan, keterampilan dan sikap peserta didik dalam mengamalkan ajaran 
agama pada semua jalur, jenjang dan jenis pendidikan. Sementara dalam Peraturan Pemerintah No 55 tentang Pendidikan Agama dan Keagamaan dijelaskan bahwa pendidikan agama diberikan pada satuan pendidikan dan diberikan sekurang-kurangnya dalam bentuk mata pelajaran dengan tujuan berkembangnya peserta didik dalam memahami dan mengamalkan nilai-nilai agama yang mengimbangi penguasaannya dalam ilmu pengetahuan, teknologi dan seni. Dengan demikian pendidikan agama diharapkan mampu membangun watak dan kultur bangsa yang religius, tidak semata dalam aspek ritus dan peribadatan tetapi justru refleksi spirit keagamaan dalam seluruh perbuatan professional dan sosial masyarakat Indonesia.

Pendidikan keagamaan adalah pendidikan yang mempersiapkan peserta didik untuk menjalankan peranan yang menuntut penguasaan pengetahuan tentang ajaran agama dan/atau ahli ilmu agama dan mengamalkan ajaran agamanya. Dengan demikian, pendidikan keagamaan bertujuan untuk membentuk peserta didik yang memahami dan mengamalkan nilainilai ajaran agamanya dan/atau menjadi ahli ilmu agama yang berwawasan luas, kritis, kreatif, inovatif dan dinamis dalam rangka mencerdaskan kehidupan bangsa yang beriman, bertakwa dan berakhlak mulia. Merujuk pada pengertian ini, ada perbedaan mendasar antara pendidikan agama dan pendidikan keagamaan. Pendidikan agama diberikan sebagai upaya membina ketakwaan peserta didik dan mampu merefleksikan sikap dan tindak ketakwaannya itu dalam seluruh perbuatan profesi dan sosialnya. Sementara pendidikan keagamaan adalah jalur dan jenis pendidikan yang lebih memperbesar penawaran pelajaran agama, dengan tujuan membina calon ahli-ahli ilmu agama (Islam), yang tidak saja membentuk kepribadian religius pada dirinya, tetapi juga dapat memberikan pembinaan keagamaan pada orang lain. Maka tidaklah fair untuk mengkaji pendidikan keagamaan sebagaimana definisi di atas bagi kalangan anak jalanan. Maka yang dimaksud pendidikan keagamaan dalam penelitian ini adalah bagaimana praktek praktek pendidikan agama pada anak jalanan. Atau yang lebih tepat adalah bagaimana pengalaman pendidikan agama pada komunitas anak jalanan.

\section{TEMUAN DAN PEMBAHASAN \\ Profil Anak Jalanan di Kota Medan}

Anak jalanan tersebar di kota Medan, seperti penjual koran, penyemir sepatu, penjual rokok, pengamen, penjual sapu tangan atau lap kerinmgat penjual permen atau pemulung. Mereka malakukan kegiatan ini adalah karena faktor kemiskinan dan kondisi ekonomi yang dianggap sebagai faktor utama yang mendorong keberadaan anak jalanan tersebut.

Sebaran anak jalanan di kota Medan tahun 2007 yang terdata di dinas Sosial berjumlah 647 orang dengan rincian anak jalanan laki-laki sebanyak 467 orang $(72,17 \%)$ dan anak jalanan perempuan sebanyak 180 orang (27,82\%). Terlihat angka anak jalanan laki-laki relatif lebih banyak dibanding anak perempuan. Ini mengisyaratkan bahwa Anak laki-laki yang akan menjadi calon-calon penerus bangsa dan pembangunan di masa depan masih ada yang tumbuh di jalanan. Kondisi yang demikian ini tentunya sangat memprihatinkan kita semua.

Tabel 1. Sebaran anak jalanan di kota Medan tahun 2007 menurut umur

\begin{tabular}{|l|l|l|l|}
\hline \multicolumn{1}{|c|}{ No } & \multicolumn{1}{c|}{ Umur } & \multicolumn{1}{c|}{ Jumlah } & \multicolumn{1}{c|}{$\%$} \\
\hline 1. & $4-6$ tahun & 86 orang & $13,29 \%$ \\
\hline 2. & $7-12$ tahun & 169 orang & $26,12 \%$ \\
\hline 3. & $13-15$ tahun & 212 orang & $32,76 \%$ \\
\hline 4. & 16 tahun $>$ & 180 orang & $27,82 \%$ \\
\hline
\end{tabular}


Adapun sebaran anak jalanan di kota Medan tahun 2007 menurut umur, anak jalanan yang berumur antara 4-6 tahun sebanayak 86 orang 13,29\%\%), yang berumur antara 7-12 tahun sebanyak 169 orang $(26,12 \%)$, yang berumur antara 1315 tahun sebanyak 212 orang $(32,76 \%)$ dan umur 16thn keatas sebanyak 180 orang $(27,82 \%)$.

Dari data diatas terlihat angka anak jalanan usia 7-12 tahun relatif tinggi yaitu 26,12\% dan usia antara 13-15 tahun yang Ipaling tinggi yaitu 32,76\%. Ini mengisyaratkan bahwa pada krisis multidimensi, mengakibatkan semakin banyak anak-anak usia sekolah terkena dampaknya. Walaupun ada program wajib belajar 9 tahun, tapi bagi mereka yang pendapatannya rendah, biaya Pendidikan masih dianggap mahal terutama untuk biaya pendukung (buku dan transport).

Meskipun krisis ekonomi bukan satu-satunya penyebab terbengkalainya Pendidikan anak-anak usia sekolah, namun ada korelasi kuat semakin luasnya krisis ekonomi diikuti pula oleh makin banyaknya anak-anak tidak berada di ruang sekolah lagi. Pada jam-jam sekolah, mereka berhamburan di mana-mana, bahkan berada di jalanan untuk hidup bebas, lari dari keluarga/rumah atau untuk mencari tambahan pendapatan keluarga dengan menjadi pengamen, pemulung, pengasong, pengemis, dan lain-lain. Tidak bisa tidak, angka anak jalanan meningkat tajam.

\section{Karakteristik Anak Jalanan}

Dinas Sosial Kota Medan mendefinisikan Anak jalanan sebagai anak yang sebagian besar menghabiskan waktunya untuk mencari nafkah atau berkeliaran di jalanan atau tempat-tempat umum lainnya. ${ }^{1}$ Jadi Anak jalanan yang menjadi

1 Intervensi Psikososial,, (Jakarta: Departemen Sosial, Direktorat Kesejahteraan Anak, keluarga dan lanjut usia, 2001) h. 20 subyek penelitian di kota Medan adalah anak yang menghabiskan sebagian besar, waktunya berada diluar rumah atau ditempat umum mencari nafkah untuk dirinya dan keluarganya dan berumur di bawah 18 tahun. Selanjutnya karakteristik anak jalanan secara garis besar di bedakan dalam tiga kelompok:2 Pertama, anakanak yang mempunyai kegiatan ekonomi sebagai pekerja anak di jalan, tetapi masih mempunyai hubungan yang kuat dengan orang tua mereka. Sebagian penghasilan mereka dijalanan adalah untuk membantu memperkuat penyangga ekonomi keluarganya karena beban atau tekanan kemiskinan yang mesti di tanggung tidak dapat diselesaikan sendiri oleh kedua orang tuanya.

Kedua, anak-anak yang berpartisipasi penuh dijalanan, baik secara sosial maupun ekonomi. Beberapa diantara mereka masih mempunyai hubungan dengan orang tuanya, tetapi frekwensi pertemuan mer-eka tidak menentu. Banyak diantara mereka adalah anak-anak yang karena suatu sebab biasanya kekerasan lari atau pergi dari rumah. Ketiga, anak-anak yang berasal dari keluarga yang hidup di jalanan. Meskipun anak-anak ini mempunyai hubungan kekeluargaan yang cukup kuat, tetapi hidup mereka terombangambing dari satu tempat ke tempat yang lain dengan segala resikonya. Salah satu ciri penting dari kategori ini adalah anak jalanan yang sejak anak masih bayi bahkan sejak masih dalam kandungan diajak ibu atau orang tuanya untuk mengemis di jalanan Di Indonesia kategori ini dengan mudah ditemui diberbagai kolong jembatan, rumah-rumah liar sepanjang rel ker-eta api dan sebagainya.

Menurut Dinas sosial kota Medan, anak jalanan dikelompokkan dalam tiga kategori: (1) Anakjalanan yang hidup di jalanan, de-

2 Surbakti dkk, Prosiding Lokakrya Persiapan Survei Anak rawan (Jakarta: Kerjasama BPS dan UNICEF, 1997). 
ngan kriteria: Putus hubungan atau lama tidak ketemu dengan orang tuanya; 8-10 jam berada di jalanan untuk "bekerja" (mengamen, mengemis, memulung) dan sisanya menggelandang/ tidur; Tidak lagi sekolah; Rata-rata berusia di bawah 14 tahun, (2) Anak jalan yang bekerja di jalan, dengan kriteria: berhubungan tidak teratur dengan orang tuanya; 8-16 jam berada di jalanan; mengontrak kamar sendiri, bersama teman, ikut orang tua/ saudara, umumnya didaerah kumuh; Tidak lagi sekolah; Pekerjaan; penjual koran, pengasong, pencuci bus, pemulung, penyemir sepatu, dll; Rata-rata berusia dibawah 16 tahun (3) Anak yang rentan menjadi anak jalanan, dengan kriteria: Bertemu taratur setiap hari / tinggal dan tidur dengan keluarganya; 4-5 jam kerja dijalanan; Masih bersekolah; Pekerjaan; penjual koran, penyemir, pengamen, dll); Usia rata-rata di bawah 14 tahun.

Selanjutnya Dinas sosial kota Medan membagi beberapa tipologi anak jalanan yaitu:

a) pengamen di lampu merah, terminal, bis, warung makan,

b) mengemis dipasar, pertokoan " lampu merah, bis, tempat umum,

c) menjual jasa; angkut belanjaan, semir sepatu, membersihkan kaca,

d) menjual kantong kresek,

e) pemulung barang bekas ditempat sampah, pertokoan, pasar, rumah penduduk.

Undang-undang perlindungan anak didasari atas hak anak non diskriminasi yang terbaik buat anak, hak untuk hidup dan berkembang serta berpartisipasi. Salah satu bentuk perlindungan bagi anak di kota Medan adalah dalam bentuk pemenuhan hak berkembang dalam memperoleh Pendidikan ketrampilan untuk kelangsungan hidup secara mandiri dan berkualitas, berupa: pelatihan bengkel, salon, tataboga, dan sablon.

Jika dikaitkan dengan kelompok anak jalan yang telah disebutkan, maka anak jalanan dari temuan penelitian diantaranya beberapa anak jalanan kembali ke rumah, sebagian yang lain tinggal di jalan atau rumah singgah. Ada juga di antara mereka yang tinggalnya tidak menentu, sesukanya. Mereka rata-rata tamatan SD/MI dan SMP/MTs.

Penelitian dilakukan di beberapa tempat meliputi: Jl. A. Yani, Lampu Merah Kota Medan, Terminal angkot Kota Medan. Dalimunte (anak jalanan yang bekerja di jalan) misalnya menjelaskan selesai ngamen dari jam 12.00 - 21.00, dia kadangkadang nginap di jalan dekat perempatan lampu merah Medan, tapi kadang-kadang juga tinggal di rumah kontrakannya yang terletak di pemukiman kumuh, tidak permanen dengan dinding dari papan yang sudah mulai rapuh. Sedangkan Simorangkir (14 tahun) yang juga termasuk katagori anak yang rentan menjadi anak jalanan. Sepulang sekolah, ngamen dari jam 13.0020.00 di perempatan lampu merah Medan kota, kemudian pulang ke rumah dengan dijemput orang tuanya.

Berbeda dengan Sulaiman (13 tahun) yang bernama asli Mustaqim yang termasuk katagori anak jalanan yang hidup di jalan. Hidup sehari-harinya dipakai untuk ngamen dan main game dari jam 10.00 22.00 di Kota Medan, dia tinggal kadangkadang di emper toko, di terminal dan di taman K3.

\section{Profesi Anak Jalanan}

Profesi pokok mayoritas anak-anak jalanan di Kota Medan adalah sebagai pengamen (di lampu rnerah, terminal, dibus, warung makan), pengemis (di pasar, pertokoan, dilampu merah dan dibus atau tempat umum lainnya.), menjual jasa ( seperti angkut belanjaan dipasar pertokoan, semir sepatu, membersihkan kaca mobil ), menjual (seperti kantong kresek, menjual rokok), pemulung barang bekas (ditempat sampah, pertokoan, pasar atau dirumah penduduk). Peng- 
hasilan mereka perharinya tidak menentu. Seperti Sulaiman (13 thn), Nababan (12 thn), Dalimunte (12 thn), Mustaqim(13 thn) yang berprofesi sebagai pengamen di perempatan lampu merah, rata-rata penghasilan merekaRp. 25.000 sampai Rp 30.00. Pengemis antara Rp. 15.000 - Rp 50.000 .

Sedangkan penghasilan Nababan(17 tahun) yang profesinya pemulung "Burtok" bubaran toko dari jam 12.00 - 15.00 dan jam 21.00 - 24.00 di Garuda pertokoan kota Medan penghasilannya berkisar antara Rp. 17000 sampai Rp. 30.000 .

Salim (14 tahun) yang tamatan Madrasah Ibtidaiyah (MI) menuturkan bahwa dari hasil berjualan kantong plastik di pasar penghasilannya bisa mencapai antara Rp. 7000 sampai Rp. 14.000. Penghasilan yang di dapat dari anak jalanan didistribusikan diantaranya untuk: membantu ekonomi keluarga, keperluan pribadi (makan, beli pakaian, dan biaya sekolah), main game.

Penyebab Timbul dan Tumbuhnya Anak Jalanan

Sementara itu banyak orang mengira bahwa faktor utama yang menyebabkan anak turun kejalan untuk bekerja dan hidup di jalan adalah karena faktor kemiskinan. Namun dilapangan muncul fakta bahwa kemiskinan bukanlah satu-satunya faktor penyebab anak turun ke jalan. Mereka yang akhirnya menjadi anak jalanan bisa disebabkan berbagai faktor, diantaranya tingkat mikro (faktor yang berhubungan dengan anak dan keluarga) yaitu: (1) faktor pendorong: keadaan ekonomi keluarga yang semakin dipersulit oleh kebutuhan yang ditanggung kepala keluarga, sehingga tidak mampu memenuhi kebutuhan keluarga, maka anak-anak disuruh ataupun dengan sukarela membantu mengatasi kondisi ekonomi tersebut, ketidakserasian dalam keluarga, sehingga anak tidak betah tinggal di rumah atau lari dari keluarga, Adanya kekerasan atau perlakuan salah dari orang tua terhadap anaknya sehingga anak lari dari rumah, kesulitan hidup di kampung, anak melakukan urbanisasi untuk mencari pekerjaan mengikuti orang dewasa (2) faktor penarik: kehidupan jalan yang menjanjikan, dimana anak mudah mendapatkan uang, anak bisa bermain dan bergaul dengan bebas, diajak teman.

Silaban (13 tahun), misalnya, sejak kecil ditingal orang tuanya dan tidak punya keluarga. Sekarang tidak melanjutkan sekolah. Untuk memenuhi kebutuhan hidupnya dia menjadi pengemis setelah orang tunya meninggal. Lain halnya dengan Zainal (13 thn) yang sudah putus sekolah, orang tuanya Mudzakir yang pekerjaan sehari-harinya tukang becak dengan Pendidikan yang rendah dan emempunyai saudara kandung lima orang. Perilaku orang tua yang sering memukul anak, membuat Zainal takut dan lari dari rumah yang akhirnya membuat dia menjadi pengamen di jalan. Di jalan dia menemukan kebebasan dan merasa enjoy.

Sedangkan Salim (12 tahun) menjadi pengamen di perempatan lampu merah menjadi anak jalanan karena diajak oleh temannya dan ingin tahu lebih banyak tentang dunia luar. Pagi hari Salim pergi ke sekolah. Sepulang dari sekolah (SD) jam 14.00 , dia berangkat dari rumahnya menuju lampu merah untuk menjadi pengamen sampai jam 20.00. Kondisi orangtua Salim yang pekerjaannya menjadi TKI sehingga Salim kurang mendapat perhatian dan kepedulian dari orangtuanya.

Ada kisah yang menarik dari contoh anak jalanan yang satu ini. Zawawi (17 tahun) yang drop out dari Sekolah Dasar dan sekarang menjadi pemulung. Dia menuturkan keputusan menjadi anak jalanan karena ayahnya (Rasiman) yang berprofesi sebagai pemulung juga, tidak mampu utuk memenuhi kebutuhannya. Seakan-akan tergambar disini bah- 
wa pekerjaan sebagai pemulung sudah menjadi profesi turun temurun.

Eksploitasi oleh orang tua juga dialami oleh Neneng. Dia harus membantu orang tua mencari nafkah. Sedangkan bapaknya menganggur. Dia menjadi pengamen pada mulanya diantar jemput oleh orang tuanya. Sepulang dari sekolah jam 14.00, dia diantar orang tuanya ke jalan perempatan lampu merah untuk ngamen, kemudian akan di jemput pulang jam 20.00. Neneng yang masih sekolah di kelas V Sekolah Dasar ini terpaksa harus membantu orangtuanya mencari nafkah untuk "menghidupi" bapaknya yang tidak bekerja. Kadang Neneng tidak pergi ke sekolah demi untuk mencari uang dan hasil jerih payahnya menjadi pengamen diambil orang tuanya.

Kisah-kisah anak jalanan, tersebut menjelaskan mengenai penyebab anak turun ke jalan pada tingkat mikro (faktor yang berhubungan dengan anak dan keluarga). Adapun pada tingkat makro (strukur masyarakat), faktor-faktor penyebab keberadaan anak jalanan adalah: (1) Ekonomi, adanya peluang pekerjaan sektor informal yang tidak terlalu membutuhkan modal dan keahlian, mereka harus lama dijalanan dan meninggalkan bangku sekolah, ketimpangan desa dan kota yang mendorong urbanisasi, (2) Pendidikan, biaya sekolah yang tinggi, prilaku guru yang diskriminatif, dan ketentuan-ketentuan teknis dan birokratis yang mengalahkan kesernpatan belajar, dan (3) Belum beragamnya unsurunsur pemerintah memandang anak jalanan antara sebagai kelompok yang memerlukan perawatan (pendekatan kesejahteraan) dan pendekatan yang menganggap anak jalanan sebagai irouble maker atau pembuat masalah (security approach) pendekatan keamanan).

\section{Pola Kepemimpinan}

Kondisi anak-anak jalanan di Kota Medan pada umumnya hidup berkelom- pok, dan ikatan di antara mereka sangat kuat. Walau mereka dari latar belakang dan karakter yang berbeda, tapi mereka tetap merasa senasib sepenanggungan. Oleh karena itu, mereka akan menunjukkan solidaritasnya dan kesetiakawanan kalau ada anggota kelompoknya yang diganggu. Adapun hubungan mereka dengan masyarakat umum, mereka cuek tapi akan ramah bagi yang peduli.

Persaingan antar anak jalanan juga sering terjadi, terutama dengan mereka yang tidak masuk kelompoknya. Kadang pengamen yang baru, tidak boleh mengamen di tempat yang sebelumnya sudah dikuasai oleh pengamen lainnya. Ini akibat dari adanya ikatan-ikatan kelompok pada anak jalanan. Pola kepemimpinan pada anak jalanan yang ada hanya kepemimpinan tiap kelompok. Menurut penuturan para anak jalanan bahwa mereka memilih pemimpin kelompok berdasarkan: senioritas, umur(tua) dan alat musik yang mereka mainkan.

Tetapi kepemimpinan secara struktur organisasi yang membawahi semua kelompok tidak ada. Mereka tidak memiliki struktur organisasi yang menggerakkan, mengarahkan dan mengevaluasi kerja mereka. Mereka bebas bekerja tanpa memiliki ikatan dengan orang lain dan tidak bekerja dalam aturan-aturan yang ketat. Akibat dari kondisi ini adalah tidak ada organisasi yang membantu secara rapih dan intes untuk mengatasi kesulitan-kesulitan yang dialami para anak jalanan.

Pendidikan Keagamaan pada Anak Jalanan

Penduduk Kota Medan adalah terkenal religius. Umat Islam yang mayoritas ini menyelenggarakan kegiatan keagamaan dengan tenang, demikian juga umat agama Kristen, Katholik, Hindu, Budha dan Konghucu dapat menyelenggarakan ibadah dengan tenang, karena suasana 
kerukunan umat beragama amat kondusif. Umat Islam menyelenggarakan kegiatan sholat berjama'ah lima waktu di masjidmasjid, langgar/ musholla yang terdapat di kampung- kampung, bahkan masjid, langgar/musholla tersebut tidak saja digunakan untuk kegiatan sholat berjama'ah lima waktu saja tetapi juga digunakan untuk kegiatan majlis ta'lim, bapak-bapak dan kaum remaja serta kegiatan TPA/TKA dan kegiatan sosial lainnya ( santunan anak yatim dan fakir miskin, orang jompo dan penyaluran zakat fitrah dan pemotongan hewan qurban dan penyaluran daging hewan qurban ).

Pada setiap malam Jum'at pada umumnya umat Islam menyelenggarakan kegiatan Yasinan atau membaca surat Yasin, ada yang diselenggarakan setelah sholat Maghrib di masjid-masjid, langgarlanggar/ musholla dan ada juga yang menyelenggarakan kegiatan tersebut setelah sholat Isya bahkan ada juga sebagian umat Islam menyelenggarakan kegiatan Yasinan ini dirumah penduduk secara bergiliran sekaligus untuk bersilaturahmi. Biasanya kegiatan Yasinan ini hanya diikuti oleh orang-orang yang sudah berkeluarga, sedang para pemuda atau remaja biasanya menyelenggarakan kegiatan sendiri yaitu pengajian remaja ada yang dilaksanakan pada malam Jum'at setelah sholat Isya dan ada yang menyelenggarakan malam Minggu setelah sholat Isya'.

Demikian juga umat kristiani, umat Hindu, umat Budha dan umat Konghucu dapat menyelenggarakan kegiatan peribadatan dengan khusu' dan tenang di tempat peribadatn masing-masing ( umat Kristiani penyelenggarakan peribadatan di gereja masing-masing, umat Hindu menyelenggarakan peribadatan di Pure, umat Buha dapat menyelenggarakan peribadatan mereka di Wihara dan umat Konghucu menyelenggarakan peribadatan mereka di Klenteng).
Dengan banyaknya tempat peribatan yang seharusnya sebagian penduduk kota Medan sudah banyak yang tersentuh dengan Pendidikan agama. Tapi bagaimana dengan Pendidikan agama pada anak jalanan yang jumlahnya 647 di kota Medan. Pada umumnya anak jalanan tidak mengikuti pelajaran agama dengan rutin, bahkan ada sebagian anak jalanan yang tidak begitu mementingkan pelajaran agama, hal ini karena tidak adanya kepedulian dan contoh keluarga serta lingkungan sehingga mereka merasa tidak berdosa jika tidak melakukan kewajiban agama. Kondisi ini berdampak pada ancaman bagi anak tersebut karena bisa mengarah ke narkoba, eksploitasi, bisa dimanfaatkan oleh orang lain, hidup bebas dan bisa melakukan kriminalitas lainnya. Belum ada LSM maupun lembaga lainnya yang memiliki kepedulian secara khusus kepada anak jalanan. Kegiatan pengajian agama yang secara rutin dilaksanakan di masjid-masjid maupun di mushollamusholla belum menyentuh anak-anak jalanan bahkan sebagian masyarakat membenci dan bahkan mengucilkan anak jalanan. Padahal seharusnya anak jalanan ini didekati dan diperhatikan Pendidikan agamanya, sehingga mereka mendapat bekal ilmu pengetahuan agama yang sangat bermanfaat untuk membentengi diri mereka dari malakukan perbuatan-perbuatan asusila, narkoba dan sebagainya.

\section{Bentuk-Bentuk Pendidikan Keagamaan}

Berkenaan dengan bentuk-bentuk Pendidikan keagamaan yang diberikan kepada anak jalanan secara khusus belum ada, karena anak jalanan yang menjadi sasaran penelitian di Kota Medan, mereka ada yang masih tinggal bersama orang tuanya, ada yang tinggal di gubuk-gubuk reot di perkampungan kumuh dan ada juga yng tinggal dikolong jembatan, sehingga secara khusus belum ada perlakuan untuk memberikan Pendidikan keagamaan kepada mereka. 
Dari pengamatan yang saya lakukan terhadap masyarakat yang tinggal dipemukiman kumuh yang hampir seluruhnya penduduknya dihuni oleh pemulung dan tukang kuli panggul pasar/ kuli grobag, ketika malam jum'at sebagian mereka menghadiri langgar/mushalla At Taufiq, mereka juga ikut shalat berjamaah maghrib yang kemudian dilanjutkan dengan kegiatan membaca Surat Yasin secara rutin dan dilanjutkan dengan shalat Isya'. Bahkan mereka tidak hanya ikut dalam kegiatan Yasinan saja, tetapi mereka juga ikut aktif dalam kegiatan-kegiatan keagamaan lainnya seperti pengajian atau majlis taklim, PHBI dan lain-lainnya.Bentuk-bentuk Pendidikan keagamaan yang ada di masyarakat pada umumnya adalah :

a. Pengajian orang dewasa atau majlis taklim yang diselenggarakan di masjidmasjid dan langgar/mushalla yang terdapat di wilayah tempat tinggal mereka.

b. Kuliah Subuh yang diselenggarakan setiap hari Ahad pagi mulai jam 6.30 sampai jam 8.00 Wib bertempat di masjid Raya Medan.

c. Membaca Surat Yasin pada setiap malam Jum'at setelah shalat Maghrib.

d. Ngaji Al; Qur'an bagi anak-anak usia dini yang diselenggarakan dimasjidmasjid dan langgar/mushalla di lingkungan mereka.

Secara khusus lembaga Pendidikan keagamaan yang disediakan bagi anak jalanan tidak ada, namun Pendidikan keagamaan yang ada di masyarakat untuk orang dewasa yaitu majlis taklim dan kuliah subuh setiap hari Ahad di masjid Raya Medan dimana lokasinya tidak jauh dari tempat tinggal mereka. Untuk anakanak adalah TKA, TPA dan Diniyah

\section{Proses Pendidikan Keagamaan}

Seperti disebutkan terdahulu bahwa Pendidikan keagamaan pada anak jalanan secara khusus tidak ada, Pendidikan keagamaan pada masyarakat untuk orang dewasa adalah Pendidikan keagamaan yang berupa pengajian majlis taklim, kegiatan PHBI, kegiatan keagamaan dalam memperingati siklus kehidupan manusia, mulai dari kelahiaran, khitanan, pernikahan, tujuh bulanan, kematian ( 3 hari, 40 hari, 100 hari dst ). Sedang Pendidikan keagamaan untuk anak-anak usia dini adalah TKA, TPA dan Diniyah.

Penyelenggaraan majlis taklim ini adalah pada setiap malam Rabu bagi kaum bapak-bapak dan dilaksanakan setelah shalat Isya' sampai pukul 21.00 wib. Sedang kaum ibu-ibu menurut penuturan ustadz Qomaruddin belum ada dan Insya Allah direnanakan dibuka setelah lebaran Idul Fithri tahun 2008 dan sekarang sedang dipikirkan secara masak-masak. Kegiatan TKA/TPA untuk anak usia dini diselenggarakan di masjid-masjid dan langgar/ mushalla yang dimulai pukul 16.00 sampai pukul 17.00 wib.

\section{Ketenagaan}

Tenaga yang mengajar Pendidikan keagamaan bagi anak jalanan secara khusus belum ada, tenaga pendidik yang ada adalah Pendidikan keagamaan yang ada dimasyarakat pada umumnya seperti tenaga pengajar majlis taklim dan penceramah dalam PHBI, Khutbah Jum'at, Khutbah Idul Fithri dan Idul Adha serta ustadz yang memimpin dalam memperingati siklus kehidupan manusia.

Tidak ada persyaratan tertentu bagi tenaga pengajar pada Pendidikan keagamaan dimasyarakat, misalnya harus memiliki jenjang Pendidikan SI IAIN Fakultas Syari'ah atau Tarbiyah dsb, tetapi tenaga pengajar pada Pendidikan keagamaan di masyarakat adalah mereka yang menguasai ilmu agama Islam dengan baik dan di diabdikan kepada masyarakat dan penguasaan agama Islam tersebut diakui oleh masyarakat, meskipun mereka hanya 
memiliki latar belakang Pendidikan MA dan sederajat.

Tenaga pengajar atau ustadz yang memimpin majlis taklim mushalla At Taufiq hanya tamatan dari PGAN tetapi peguasaan ilmu agamanya sangat luas sehingga keustadzatannya di akui oleh masyarakat. Pak Qomaruddin ini tidak hanya mengisi pengajian di majlis taklim saja, tetapi dia juga memberikan ceramahceramah agama dalam PHBI dan memimpin acara tahlilan dst. Sedang tenaga pengajar TKA dan TPA adalah umumnya mahasiswa IAIN dan tamatan MA yang belum memiliki pekerjaan tetap sehingga mereka memiliki waktu untuk mengajar di TKA dan TPA. Umumnya mereka telah memiliki setifikat lqra' sehingga mereka memiliki kompetensi yang memadai untuk mengajar membaca Al Qur'an dengan baik.

\section{Materi}

Materi Pendidikan keagamaan yang di ajarkan untuk Pendidikan orang dewasa di masyarakat adalah Aqidah Akhlak, Al Qur'an Hadis, Fiqih, dan Tarikh Islam. Materi-materi tersebut biasanya disampaikan melalui metode ceramah, Tidak ada evaluasi secara tertulis, evaluasi yang dilakukan biasanya hanya penjelasan yang diberikan kepada jamaah yang menanyakan sesuatu persoalan keagamaan, yang kadang-kadang pertanyaan masyarakat tersebut tidak ada kaitannya sama sekali dengan materi pelajaran yang sedang dibahas. Menurut ustadz Syamsuddin untuk Pendidikan keagamaan bagi orang dewasa ini evaluasinya lebih ditekannkan kepada pengamalan ajaran-ajaran agama tersebut dalam perilaku kehidupan seharihari.

\section{Sarana dan Fasilitas}

Pada umumnya kegiatan Pendidikan keagamaan atau pengajian ini, dilaksanakan di masjid-masjid, mushalla- mushalla yang ada di masyarakat, sehingga fasilitas yang digunakan adalah fasilitas yang dimiliki oleh masjid dan mushalla tersebut. Pada umumnya fasilitas yang digunakan dalam kegiatan pengajian ini adalah pengeras suara dan podium, sementara fasilitas papan tulis atau white board jarang dijumpai dalam pengajian-pengajian tersebut.

4. Biaya

Dalam pembelajaran Pendidikan keagamaan atau pengajian majlis taklim, masyarakat tidak dipungut biaya atau iuran, tapi biasanya penguruslah yang mencari donatur tetap untuk keperluan pembiayaan tersebut. Menurut ustadz Jazuli pengurus mushalla At Taufiq, semua ustadz yang memberikan pengajian majlis taklim bapakbapak tidak ada yang diberi tranport atau insentif, menurut ustadz Jazuli dakwah menyampaikan ajaran agama adalah perintah agama, jadi tidak harus selalu dibayar karena ini merupakan kewajiban. Menurut beliau kalau jamaah pengajian yang hadir banyak, para ustadz sudah merasa senang dan puas, itu artinya materi yang beliau sampaikan sangat dibutuhkan oleh jamaah. Kalau masyarakat dipungut biaya dikhawatirkan jamaahnya akan habis, karena sebagian besar pengikut pengajian di mushalla At Taufiq ini adalah masyarakat kelas bawah secara sosial ekonomi maupun Pendidikan. Jadi untuk kegiatan keagamaan yang memerlukan biaya besar biasanya pengurus mencari donatur. Masyarakat dilibatkan untuk bergotong royong menyiapkan perlengkapan yang diperlukan untuk kegiatan tersebut.

\section{Hambatan dan Harapan}

\section{Hambatan}

a. Anak jalanan ini hidupnya berkelompok-kelompok kecil, misalnya pengamen, penjual kantong plastic, 
penjual rokok keliling mereka tinggal di rumah rumah bedeng atau petakan dimana satu petaknya rata-rata ukuran $3 \times 8 \mathrm{~m}$. Di rumah bedeng yang terdiri dari 4 sampai 5 pintu tersebut dihuni juga 4 sampai 5 keluarga, kemudian ditempat lain, mereka kontrak dan disana tinggal 3 keluarga, demikian juga ditempat lainnya.

b. Hambatan untuk mendapatkan akses pelayanan Pendidikan Keagamaan bagi anak jalanan dan keluarganya adalah tidak adanya lembaga Pendidikan keagamaan yang khusus diselenggarakan untuk mereka, lembaga Pendidikan keagamaan yang ada sifatnya umum, seperti majlis taklim, jamaah Yasinan dan sebagainya.

c. Dalam penanganan anak jalanan, belum ada usaha yang integrative untuk melakukan koordinasi antara: Trantib, kepolisian/keamanan, tenaga kerja, diknas, dan Dinas perhubungan untuk pengarahan dan penertiban, sedangkan Depag datang hanya untuk memberikan ceramah, jadi belum ada koordinasi yang formal dengan Depag untuk melakukan penanganan secara integrative terutama dalam hal siraman rohani, sifatnya baru pada insidental,

d. Anggaran penanganan anak jalanan masih belum memadai antara jumlah biaya yang disediakan dengan jumlah anak jalanan 647 orang,

e. Tingkat Pendidikan anak dan orang tua yang rendah membuat sulit untuk menyadarkan bahwa menjadi anak jalanan bukan pekerjaan yang baik,

f. Mengubah sikap, mental perubahan, membutuhkan waktu yang lama jadi diperlukan kesabaran dan keteguhan dalam menanganinya.

Harapan

a. Dinas Sosial mengharapkan:

1) Walau Pendidikan wajar diknas sudah berjalan dengan biaya gratis tapi, ada biaya-biaya lain yang masih terasa berat terutama dalam biaya buku, transport. Oleh karena itu Pihak Diknas harus memperhatikan hal ini agar anak jalanan banyak yang dapat menikmati Pendidikan.

2) Perlu adanya pembinaan life skill bagi anak jalanan dan pemberian modall untuk menjalankan keterampilan tersebut (ketrampilan buat kerupuk, kue). Selama ini baru ada quota dari Dinas sosial sehingga sangat terbatas penggunaanya,

3) Perlu adanya akuntabilitas dalam penggunaan anggaran anak jalanan harus diketahui berapa besarnya, untuk siapa dan digunakan untuk apa. Dengan demikian diperlukan pengontrolan dalam mengevaluasi dana anak jalanan.

b. Harapan Kementerian Agama terhadap Pendidikan keagamaan dimasa mendatang bagi anak jalanan.

1) Perlu adanya tokoh agama atau ustadz yang memperhatikan kondisi mereka dengan jalan mengunjungi tempat tinggal mereka, menyapa mereka dan berdialog dengan mereka serta mau memberikan Pendidikan keagamaan bagi orang tua dan anak-anak mereka.

2) Perlu dipikirkan kedepan adanya pengajian khusus untuk anak jalanan yang diselenggarakan dilingkungan tempat tinggal mereka

3) Untuk menarik simpati anak jalanan dalam acara santunan fakir miskin, penyaluran zakat fitrah dan penyaluran daging hewan qurban, hendaknya mereka dijadikan mustahiq.

\section{ANALISIS}

Perkembangan kota di segala bidang tampaknya tidak hanya memberikan nuansa positif bagi kehidupan masyarakat. Namun juga melahirkan persaingan hidup, sehingga muncul fenomena kehidupan yang berujung pada kemiskinan. Kota 
yang padat penduduk dan banyaknya keluarga yang bermasalah telah membuat makin banyaknya anak yang kurang gizi, kurang perhatian, kurang Pendidikan, kurang kasih sayang dan kehangatan jiwa, serta kehilangan hak untuk bermain, bergembira, bermasyarakat dan hidup merdeka. Bahkan banyak kasus yang menunjukkan meningkatnya penganiayaan terhadap anak-anak, mulai tekanan batin, kekerasan fisik, hingga pelecehan seksual, baik oleh keluarga sendiri, teman, maupun orang lain.

Dewasa ini, pertumbuhan anak jalanan di Indonesia semakin meningkat, terutama di kota-kota besar. Medan adalah salah satu contoh, dimana kita akan sangat mudah menemui anak jalanan di berbagai tempat, mulai dari perempatan lampu merah, terminal, pasar, pertokoan, dan bahkan maal. Sudah menjadi rahasia umum, bahwa biasanya mereka memang dikoordinir oleh kelompok yang rapi dan profesional, yang sering disebut sebagai mafia anak jalanan. Setiap anggota kelompok ini mempunyai tugasnya. Ada yang melakukan mapping di setiap perempatan jalan, ada yang mengatur antar jemput dan sebagainya. Mafia ini mengeksploitasi anak-anak dan menjadikannya sebagai sebuah ladang bisnis. Dan yang lebih memprihatikan, kondisi ini seringkali atas persetujuan dari orang tua mereka sendiri, bahkan juga tak jarang berperan sebagai bagian dari mafia anak jalanan.

Adapun penyebab utama menjadi anak jalanan adalah Penganiayaan kepada anak, meliputi penganiayaan mental dan fisik, selain itu juga faktor dorongan kebutuhan ekonomi, yang membuat mereka harus bekerja untuk membantu orang tua dan keluarga. Fenomena anak jalanan merupakan akses lingkaran setan kemiskinan bangsa. Kendala yang dihadapi adalah mobilitas anak-anak jalanan yang cukup tinggi. Anak- anak yang dibimbing di rumah singgah setelah keluar tak jarang yang kembali lagi ke jalanan. Fenomena ini seringkali terjadi walapun pihak rumah singgah telah memberikan sekolah gratis, makanan gratis dan atap untuk berlindung bagi mereka. Mengapa hal ini terjadi? Karena uang. Di jalanan, mereka dengan gampang bisa memperoleh uang tersebut.

Undang-Undang Nomor 20 Tahun 2002 dengan jelas menyebutkan, anak berhak mendapat perlindungan dari perlakuan diskriminasi, eksploitasi baik ekonomi maupun seksual, penelantaran, kekejaman, kekerasan, penganiayaan, ketidakadilan, serta perlakuan salah lainnya. Itu berarti, bukan hanya orang tua yang bertanggung jawab, namun juga pemerintah dan masyarakat. Orang tua yang mempekerjakan anak dibawah umur, juga jelas akan mendapat sanksi.

Kasus-kasus kekerasan (fisik, psikologis, maupun seksual) yang dialami oleh anak-anak jalanan dan terungkap ke publik hanyalah sebuah fenomena "gunung es" dari problem kekerasan yang sebenarnya kerap terjadi di dalam kehidupan anak jalanan. Oleh karena itu, tidaklah terlalu berlebihan bila dikatakan bahwa anak jalanan senantiasa berada dalam situasi yang mengancam perkembangan fisik, mental dan sosial bahkan nyawa mereka. Kekerasan inilah yang melekat dalam diri anak jalanan dan membentuk kepribadian mereka di masa depan.

Sementara itu aparat penegak hukum di Indonesia selama ini belum memiliki respon yang tinggi terhadap perlindungan anak, khususnya anak jalanan. Mereka tidak menempatkan masalah perlindungan anak sebagai salah satu prioritas utama, karena memang tidak ada unsur politisnya.

Tak bisa dipungkiri, bahwa anak jalanan belakangan telah menjadi suatu fenomena sosial yang sangat penting dalam kehidupan kota besar. Kehadiran mereka seringkali dianggap sebagai cermin kemiskinan kota. Di mata sebagian anggota 
masyarakat, keberadaan anak jalanan hingga kini masih di anggap sebagai "limbah" kota yang harus disingkirkan. Namun siapa yang ingin jadi anak jalanan? Tak satupun dari mereka yang menginginkan dirinya menjadi anak jalanan. Bahkan mungkin mereka sering kali bertanya, mengapa dilahirkan sebagai orang miskin. Jika mereka bisa menuntut keadilan, keadilan dari siapakah? Siapa yang peduli terhadap suara dan nasib mereka? UUD 1945 pasal 34 ayat 1 dengan jelas mengamanatkan, fakir miskin dan anak terlantar dipelihara oleh negara. Oleh karena itu sudah seharusnya pemerintah terus berjuang mencari strategi efektif penanganan kemiskinan dan nasib anak-anak terlantar. Tetapi anak jalanan sepertinya memang masih harus tetap berjuang sendirian.

Beberapa strategi untuk menangani anak jalanan: pertama metode struktural, yaitu melalui pendekatan kebijakan legal formal yang dapat memberikan jaminan perlindungan dan pengembangan diri bagi anak-anak jalanan. Kedua metode fungsional, yaitu melalui program-program penanganan yang selama ini banyak dilakukan untuk menangani anak jalanan. Sasaran operasioal pendekatan fungsional ini adalah usaha preventif dan kuratif bagi anakanak jalanan sehingga memungkinkan mereka mendapatkan kehidupan yang lebih baik. Ketiga metode normatif, seperti pendekatan fungsional namun relatif lebih bersifat nonfisik, seperti pendekatan ruhani spiritual dan bantuan dari berbagai pihak.

Model penanganan dapat dilakukan: (a) secara fungsional berupa Sistem PANJALU yaitu: konsep penanganan anak Anak Jalanan Terpadu, (b) secara fungsional, yaitu melalui program-program penanganan yang selama ini banyak dilakukan untuk menangani anak jalanan. Sasaran operasioal pendekatan fungsional ini adalah usaha preventif dan kuratif bagi anakanak jalanan sehingga memungkinkan mereka mendapatkan kehidupan yang lebih baik, (c) secara struktural yaitu melalui pendekatan kebijakan legal formal yang dapat memberikan jaminan perlindungan dan pengembangan diri bagi anak-anak jalanan, dan (d) secara normatif, seperti pendekatan fungsional namun relatif lebih bersifat nonfisik, seperti pendekatan ruhani spiritual dan bantuan dari berbagai pihak.

\section{PENUTUP}

\section{Kesimpulan}

1. Anak jalanan adalah kurang mendapatkan perhatian dan kasih sayang dari orang tuanya yang secara ekonomi dan Pendidikan rendah, pada umumnya mereka belum mendapatkan pelayanan Pendidikan keagamaan Islam secara baik, sementara pelayanan Pendidikan keagamaan yang ada lebih bersifat umum dan belum menjangkau mereka.

2. Anak jalanan mengalami kesulitan dalam mengakses Pendidikan keagamaan karena selama ini belum ada satu ustadzpun atau satu lembagapun yang yang memberikan pelayanan pndidikan keagamaan secara khusus kepada mereka sementara Pendidikan keagamaan yang ada masih bersifat umum.

\section{Rekomendasi}

1. Perlu adanya upaya yang dilakukan oleh Kementerian Agama, menugaskan para dai atau relawan untuk memberikan pelayanan Pendidikan keagamaan kepada anak jalanan di lingkungan tempat tinggal mereka.

2. Para ulama, tokoh agama dan dermawan hendaknya memikirkan kehidupan anak jalanan dan keluarganyal dengan cara memberikan santunan, menyalurkan zakat fitrah dan menyalurkan daging hewan qurban kepada mereka.

3. Perlu adanya koordinasi antara instansi terkait dalam hal ini Kementerian Agama, Diknas, Dinas Sosial dan LSM dalam penangan anak jalanan, baik dalam hal memberikan bantuan dalam rangka pengentasan kemiskinan, pelayanan 
Pendidikan dan Pendidikan keagamaan.

\section{SUMBER BACAAN}

Chaniago A. Andrinof (2001): Gagalnya Pembangunan: Kajian Ekonomi Politk terhadap Krisis Indonesia. Jakarta, LP3ES.

Creswell, John W. (1994): Research Design Qualitative \& Quantitative Approaches, California, SAGE Publication

Intervensi Psikososial, (Jakarta: Departemen Sosial, Direktorat Kesejahteraan Anak, keluarga dan lanjut usia,2001).
Nurharjadmo, Wahyu (1999): Sesksualitas Anak Jalanan, Yogyakarta, Pusat Penelitian Kependudukan Universitas Gajah Mada.

Surbakti dkk, Prosiding Lokakrya Persiapan Survei Anak rawan (Jakarta: Kerjasama BPS dan UNICEF, 1997).

Twikromo, Argo.Y (1999): Gelandang Yogyakarta: Suatu Kehidupan dalam Bingkai Tatanan Sosial Budaya"Resmi", Yogyakarta, Universitas Atma Jaya.

Undang-Undang Sistem Pendidikan Nasional Nomor 20 Tahun 2003

Undang-Undang Nomor 21 tahun 2007 